\title{
The elements of stem cell self-renewal: a genetic perspective
}

\author{
Gregory Pazianos, Mweia Uqoezwa, and Tannishtha Reya
}

BioTechniques 35:1240-1247 (December 2003)

\begin{abstract}
Every day, the body produces billions of new blood cells. Each of these is derived from a rare cell in the bone marrow called the hematopoietic stem cell (HSC). Because most mature blood cells have a limited lifespan, the ability of HSCs to self-renew and replenish the mature cell compartment is critical to sustaining life. While great progress has been made in isolating HSCs and defining their functional and phenotypic characteristics, the molecular mechanisms that regulate their self-renewal remain a mystery. Over the last few years, alterations in HSC frequency and self-renewal capacity in transgenic and knock-out mice have led to the identification of novel mediators of HSC homeostasis in vivo. These genetically modified mice have revealed that maintenance of survival, proliferation, quiescence, and normal telomere length all contribute to the self-renewal of HSCs. They also highlight the need to test in context of the normal microenvironment the role of signaling molecules such as Notch and Wnt, which have emerged recently as important regulators of HSC self-renewal. The emerging picture these data provide of the regulation of self-renewal in HSCs has provided a better understanding of the basic biology of stem cells and holds promise for designing strategies to improve bone marrow transplantation.
\end{abstract}

\section{IDENTIFICATION AND ISOLATION OF HEMATOPOIETIC STEM CELLS}

Hematopoietic stem cells (HSCs) are responsible for generating all the cells of the blood. Since their original identification almost 40 years ago (1), our understanding of HSCs has progressed at a remarkable rate. HSCs have been successfully isolated from the bone marrow, and stages through which they progress during commitment have been mapped in detail. Many different methods have been utilized to isolate these cells, including fluorescence activated cell sorting (FACS), based on the expression of Rhodamine 123 (2), Hoechst 33342(3), wheat germ agglutinin (4), CD34 (5), and Flk-2 $(6,7)$. One approach that has been used extensively has been to utilize antibodies to a variety of cell surface molecules, such as c-kit, Sca-1, and Thy1.1, and hematopoietic lineage markers like B220, CD3, and Mac-1 (lin). This approach has identified a small population of cells $\left(\mathrm{c}-\mathrm{kit}^{+}\right.$ Sca- $1^{+}$lin ${ }^{\mathrm{lo} /-}$ Thy $\left.1.1^{\mathrm{lo}}\right)(8,9)$ that migrate to the appropriate microenvironments and undergo rapid expansion and differentiation upon transplantation into lethally irradiated mice. In the short term, they provide radioprotection, generating the erythroid and myeloid cells that are necessary for survival; subsequently, they begin to self-renew and generate other hematopoietic cells and can maintain steady-state hematopoiesis for the lifetime of the animal $(9,10)$. The HSCs identified by such methods make up $0.05 \%$ of the total bone marrow and have been further separated into two populations: $(i)$ long-term HSCs $\left(\mathrm{ckit}^{+} \mathrm{Sca}^{+} \mathrm{Lin}^{-} \mathrm{Thy} 1.1^{\mathrm{lo}}\right.$ cells, present at 1:10000 in the marrow); and (ii) short-term HSCs (ckit $^{+}$ $\mathrm{Sca}^{+} \mathrm{Lin}^{\mathrm{lo}} \mathrm{Thy} 1.1^{\mathrm{lo}}$ cells, present at a frequency of 1:2000 in the marrow). In general and for the purposes of this review, cells that can self-renew and are capable of reconstitution of all hematopoietic lineages are referred to as stem cells, and those that have more restricted differentiation potential and can generate only a subset of lineages are referred to as progenitors.

\section{CONTROL OF HEMATOPOIETIC STEM CELL SELF-RENEWAL}

Although HSCs readily undergo self-renewal in vivo, it has been extremely difficult to identify the signals that regulate this process and recapitulate them in vitro. Over the last few years, alterations in HSC numbers and self-renewal capacity in transgenic and knock-out mice have identified new mediators of HSC homeostasis in vivo. Here we review these studies and discuss their implications for a better understanding of the molecular control of self-renewal in vivo. If these findings can be extended to human HSCs, they may advance our ability to manipulate self-renewal ex vivo and have significant impact on improving transplantation-based therapies. 


\section{THE ROLE OF SURVIVAL IN SELF-RENEWAL}

For stem cells to self-renew, they must be able to proliferate extensively without dying or differentiating. Regulators of these processes-proliferation, differentiation, and deathhave all been implicated in control of HSC self-renewal. The importance of apoptosis in this process is most clearly seen in studies of $H 2 K-B C L-2$ transgenic mice $(11,12)$. BCL-2 transgenic mice have a higher proportion of long term HSCs in the bone marrow than wild-type mice. However, these HSCs cycle at a lower rate, suggesting that the increased cell number is a consequence of inhibiting cell death alone and not of increased proliferation. In fact, the lower number of cells in cycle also suggests that Bcl-2 is preventing their entry into the cell cycle and maintaining cells in a quiescent state as observed in other cell types $(13,14)$. At a functional level, HSCs from the $H 2 \mathrm{~K}$ $B C L-2$ mice display increased colony formation and protection from growth factor-deprived death in vitro as well as greater contribution to the total blood pool in vivo compared to wildtype mice in competitive transplantation experiments $(11,12)$. These data show that anti-apoptotic signals and perhaps increased quiescence contribute to regulating stem cell numbers as well as the efficiency of reconstitution.

The importance of normal survival mechanisms to maintain self-renewal is underscored by the decreased self-renewal exhibited in Bmi1-deficient mice $(15,16)$. Bmil, a polycomb group transcription factor involved in repressing expression of homeobox genes, is overexpressed in cancer cells and can cooperate with other oncoproteins such as myc to contribute to leukemogenesis. Bmil-deficient mice display hypocellular bone marrow, and while they are found to have similar numbers of multipotent progenitors as wild-type mice, they display a 10-fold reduction of postnatal KTLS HSCs (cells that are $\left.\mathrm{c}-\mathrm{kit}^{+} \mathrm{Thy} 1.1^{\mathrm{lo}} \mathrm{Lin}-\mathrm{Sca}-1^{+}\right)$. In competitive repopulation experiments in which bone marrow HSCs from $\mathrm{Bmi}^{-1^{-/}}$mice were injected into irradiated mice in conjunction with bone marrow HSCs from wild-type mice, mutant HSCs were able to reconstitute the hematopoietic system only transiently, and all $\mathrm{Bmil}^{-/-}$-derived hematopoietic cells were depleted by 10 weeks. These data suggest an intrinsic requirement for Bmi1 in the maintenance of HSC self-renewal. Gene expression analysis of wild-type and $\mathrm{Bmil}^{-/}$bone marrow cells demonstrates that the loss of Bmi1 led to the up-regulation of p16 Ink4a and p19 Arf, genes derived from the ink4a locus and previously shown to be targets of Bmil in embryonic fibroblasts (17). The enforced expression of p19arf led to increased cell death of HSCs, which could be inhibited by the loss of p53. Additionally, the overexpression of p16 led to an inhibition of HSC proliferation. These data suggest that growth arrest due to p16 up-regulation coupled with the apoptotic consequences of p19 overexpression may lead to the impaired self-renewal observed in Bmi1-deficient HSCs. Since p16 and p19 have been previously suggested to mediate Bmil action in oncogenesis, this study reiterates the parallels that lie between the molecular mechanisms that regulate processes of self-renewal and transformation (18). Additionally, the recent finding that Bmi1 also regulates stem cell renewal of the peripheral and central nervous systems suggests that Bmil can act as a signal for stem cell maintenance in diverse tissues (19).

\section{PROLIFERATION AND QUIESCENCE IN SELF- RENEWAL}

While apoptosis clearly plays a role in maintaining selfrenewal, regulation of normal proliferation is also critical. The homeobox genes $H O X B 3$ and $H O X B 4$ appear to play a direct role in proliferation. HoxB 4 has been recently implicated as a mediator of expansion of primitive hematopoietic stem cells ex vivo (20). In contrast, HoxB3 overexpression has been found to lead to a block in lymphoid development and leads to a myeloproliferative disorder. The common expression of both genes in $\mathrm{CD} 34^{+}$progenitors prompted Bjornsson et al. (21) to delete the two contiguous genes that were flanked by loxP sites and then targeted by the Cre recombinase expression. While $\mathrm{HoxB}^{-/-}$mice have previously been shown to have skeletal abnormalities leading to lethality, the conventional mutation has not been previously reported to have any effects on hematopoiesis (22). Interestingly, the HoxB3/B4 mutant does not display the skeletal abnormalities observed in $\mathrm{HoxB}^{-/-}$mice, suggesting a fundamental difference in the nature of the deletion that remains unresolved (21). On the other hand, HoxB3/B $4^{-/-}$mice have significantly decreased cellularity in multiple hematopoietic organs, including the spleen and bone marrow (21). While HSCs from HoxB3/B $4^{-1-}$ mice do not display any defects in migration or differences in frequency of HSCs under conditions in which cells are forced to undergo in vitro expansion, primitive hematopoietic progenitors from HoxB4/B3 mutant mice display reduced proliferative ability. Additionally, twice as many mutant HSCs as wild-type HSCs remain in G0/G1 phase of the cell cycle after treatment with the cytotoxic drug cyclosphosphamide. These results suggest that the coordinate loss of both HoxB3 and $B 4$ leads to a delayed activation and recruitment into proliferation after hematopoietic stress (21). However, given the robust ability of ectopically expressed HoxB4 to maintain the self-renewing state of HSCs in vitro and in vivo after transplantation (20), the lack of more profound defects in the $H o x B 3 / B 4^{-/-}$mice is puzzling and may suggest some level of redundancy within the Hox gene family.

This possibility is supported by the more severe defects in HSC renewal and function that occur in Pbx-1-deficient HSCs. Pbx-1, a homeodomain protein and the mammalian homolog of the extradenticle protein, serves as a cofactor for Hox proteins and enhances their DNA binding affinities (22a). $P b x-1^{-/-}$mice die of anemia and other developmental abnormalities at embryonic day 15-16. While establishment of primitive and definitive hematopoiesis is intact in $\mathrm{Pbx}-1$ deficient mice, HSC containing populations from $\mathrm{Pbx}-\mathrm{I}^{-/-}$ mice were unable to reconstitute the peripheral hematopoietic system in competitive repopulation experiments (22a) and exhibit reduced colony formation in vitro and colony-forming units-spleen (CFU-S) formation in vivo. Cell cycle analysis of more differentiated progenitor populations suggests a clear reduction in the ability of $\mathrm{Pbx}$-1-deficient cells to proliferate and enter cell cycle, suggesting by extension that the loss of $\mathrm{Pbx}-1$ may also lead to impaired proliferation and subsequent exhaustion of HSCs. These also relate well to the defects in cell cycle recruitment observed in the Hox-deficient mice since $\mathrm{Hox}$ and $\mathrm{Pbx}$ may act as a transcriptional complex to al- 
low normal HSC cell cycling and renewal. However, the fact that the defects in $\mathrm{Pbx} x^{-/-}$cells are more severe suggests that $\mathrm{Pbx}$ is needed as a cofactor for a number of Hox proteins, and its loss results in several nonfunctional Hox proteins. This is also supported by the complete failure of hematopoiesis observed in mice deficient for Mll $(23,24)$, a transcription factor that regulates expression of multiple Hox genes.

While the ability to self-renew extensively is a hallmark of HSCs, the need to do so in vivo is limited by the high proliferative capacity of progenitor populations. Thus, paradoxically, HSCs in vivo are relatively quiescent. Only a small fraction of HSCs (1\%-5\% for long-term HSCs, and up to $10 \%-13 \%$ for short-term HSCs) are in cycle under normal hemeostatic conditions $(3,25)$. In fact, these abilities appear to be intricately connected, in that the ability to remain quiescent appears to be crucial for sustaining the long-term self-renewal of HSCs. This was revealed by the analysis of mice deficient for $\mathrm{p} 21^{\mathrm{cip} 1 / \mathrm{waf} 1}$, a cyclin-dependant kinase inhibitor. In $\mathrm{p} 21$ deficient mice, a greater proportion of lineage-negative cells, which includes the HSC population, were in cycle compared to the wild-type population (26). p21-deficient HSCs exhibited reduced in vitro colony formation, as well as loss of reconstitution and accelerated death in serial transplantation experiments, compared to wild-type bone marrow cells. In contrast to its role in other cell types where its deletion would be predicted to lead to increased cell cycle and thus higher numbers of cells, the loss of p21 in HSCs increased entry of HSCs into cycle and led to exhaustion and ultimate loss of the population. This suggests that excess cycling, which could potentially lead to more stem cells, cannot do so indefinitely because of a timed senescence event, such as one determined by telomere length (discussed below). Interestingly, while p21-deficient mice have increased numbers of HSCs in cycle, the loss of another cyclin-dependant kinase inhibitor, p2 7 kip1, exclusively affects progenitor proliferation and pool size but not HSCs (27). Thus, while both p21 and p27 are ubiquitously expressed, these data suggest that cell cycle kinetics and the maintenance of quiescence in stem and progenitor cell populations are regulated by distinct mechanisms. These data also identify for the first time the critical role of quiescence in maintenance of long-term self-renewal.

Defects in self-renewal also occur in mice lacking Rae28, which is a polycomb group gene (28), and Creb binding protein (CBP) (29), which is a histone acetyltransferase. Rae28 is a homolog of the Drosophila polyhomeotic gene and a member of the polycomb complex 1. Rae28-deficient fetal liver cells repopulate the hematopoietic system poorly compared to wild-type fetal liver cells in transplantation assays and display reduced ability to radioprotect and form colonies in vitro and in vivo. Intriguingly, these hematopoietic cells do not appear to have altered apoptosis or proliferation (at least in unfractionated fetal liver, although whether rare progenitor and HSC fractions may have defects remains to be tested). Similarly $\mathrm{CBP}^{+/-}$mice have multiple phenotypic abnormalities, including hematopoietic failure (30), and $\mathrm{CBP}^{-/-} \mathrm{HSCs}$ are much less efficient than wild-type HSCs in reconstituting irradiated secondary recipients. Additionally, the surface molecule Sca-1 (used extensively to isolate HSCs) appears to contribute functionally to enhance its self-renewal capacity; $\mathrm{Sca}-\mathrm{I}^{-/-}$mice display a disadvantage during competitive repopulation experiments and deficiencies during serial transplantation (31). Whether the defects in CBP-deficient and Sca1-deficient mice are due to alterations in cell death, proliferation, migration, or differentiation remains untested, and the genes that lie downstream of these molecules and may be responsible for the HSC defects seen in Rae28, CBP, and Sca-1 mutant mice will be important areas of future investigation.

\section{TELOMERES AND SENESCENCE AS MODULATORS OF SELF-RENEWAL}

Another important component of self-renewal is the maintenance of telomere length. In many cancers, the ability to proliferate limitlessly is dependent in part on the activation of telomerase, which enables the cell to maintain telomere length and subvert a normal state of senescence. While normal somatic cells do not express telomerase, high telomerase activity has also been associated with a high degree of selfrenewal in HSCs (32), and telomere length decreases with repeated transplantation of HSCs (33). Thus, if one mechanism of stem cell exhaustion is the reduction of telomere length, one prediction would be that increased or decreased telomere length may lead to greater or lesser self-renewal activity, respectively. This idea was tested recently by examining the extent of serial transplantation that can be carried out by HSCs from telomerase reverse transcriptase (TERT)-deficient and transgenic mice. While wild-type HSCs can maintain reconstitution ability for four rounds of serial transplantation, TERT $^{-/}$HSCs exhaust prematurely after two rounds of serial transplantation (34), suggesting that telomere length is indeed critical for maintaining the self-renewal ability of HSCs.

Whether extending the length of telomeres allows HSCs to extend their natural lifespan was tested by the generation of a transgenic mouse in which TERT was overexpressed using an $\mathrm{H} 2 \mathrm{~K}$ promoter (35). Overexpression of telomerase was found to increase telomere lengths in the transgenic mouse, and transgenic mice clearly maintained longer telomeres with serial transplantation. However, neither wild-type nor transgenic mouse bone marrow were able to contribute to more than four rounds of serial transplantation. This suggests that extending telomere length alone is not sufficient to extend self-renewal capacity of HSCs and that other factors must contribute to the clock that limits the HSC lifespan.

\section{HEMATOPOIETIC SPECIFICATIONAND MAINTENANCE: NOTCH, SHH, AND WNT PATHWAYS}

While the above discussion has focused on the genes that influence HSC self-renewal through analysis of genetically altered mice, another group of genes and signaling pathways have been identified as regulators of HSC self-renewal through ectopic overexpression and subsequent in vitro and in vivo analysis. These include elements of the Notch, Sonic Hedgehog (Shh), and Wnt signaling pathways, as well as HoxB4, which has been discussed above. The expression of constitutively active Notch1 in populations containing 
hematopoietic progenitors allows the establishment of immortalized cell lines that retain the potential to generate both lymphoid and myeloid cells in vitro and in long-term mouse reconstitution assays (36). Similarly, overexpression of activated Notch1 in Rag-deficient Sca ${ }^{+}$Lin $^{-}$cells allows the increased generation of HSCs in vitro and in vivo; while the cells remain multipotential, they display preferential differentiation towards the lymphoid lineage underscoring Notch1's role in enhancing lymphoid development (37). Finally, human bone marrow cells enriched for HSCs exhibit increased engraftment in vivo after being cultured in the presence of the Notch1 ligand Jagged1 in context of other growth factors (38). The fact that Notch activation has been observed to inhibit the differentiation of progenitors in many different systems (reviewed in Reference 39) supports the idea that Notch activation may promote stem cell self-renewal.

Interestingly, the predictions made by these in vitro studies are contradicted by the phenotype observed in mice that are deficient for Notch1 (40), as well as inducible Notch1 knockouts (41). In these mice there are no detectable defects in definitive HSC self-renewal or maintenance. However, analysis of embryonic Notch1-deficient mice suggests a defect in the establishment of HSC fate (40). It is of course possible that Notch1 is redundant with other Notch family members or that there is a deficiency in self-renewal that may become appar-

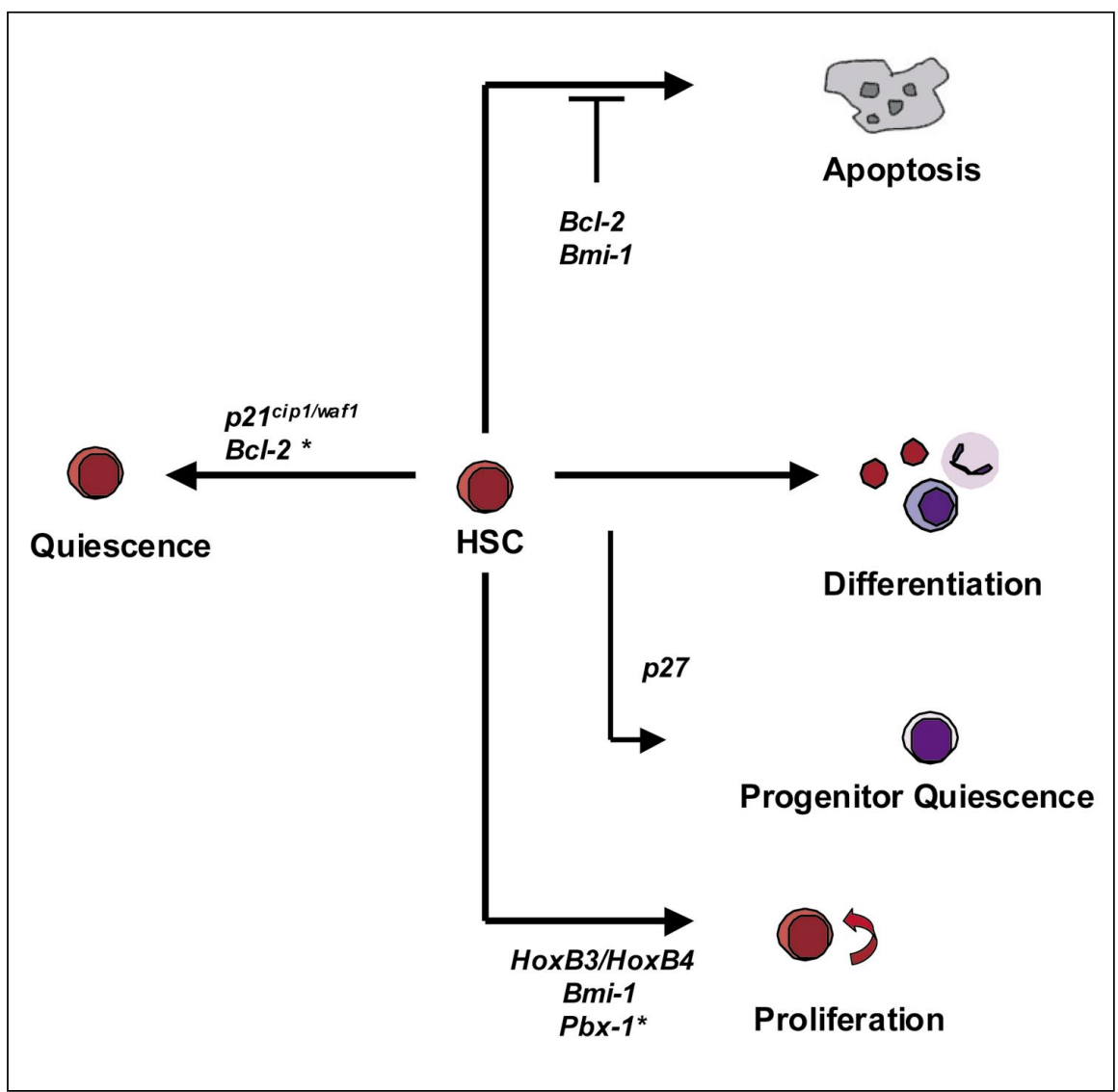

Figure 1. Overview of selected genes shown to influence elements of hematopoietic stem and progenitor cell function and self-renewal through the use of genetic mutants. Asterisks indicate those genes that have not been directly demonstrated to regulate the function indicated in hematopoietic stem cells (HSCs) but are predicted to do so based on function in related cell types. ent only through serial transplants; these possibilities have not yet been tested directly. That it may play a role that has not yet been detected is supported by very recent studies that reveal the ability of Notch signaling to regulate HSC numbers in context of the microenvironment or stem cell "niche" (42). However, another interpretation that cannot be ruled out is that while Notch1 may have the ability to drive HSCs into self-renewing divisions, it normally does not do so in vivo; furthermore, it may be important only for specification of hematopoietic fate, but not HSC maintenance. The possibility that the molecular basis of self-renewal and specification are distinct is supported by the observation that mice mutant for the stem cell leukemia (SCL) gene during embryonic life when HSC fate is being specified display a complete absence of all hematopoietic lineage cells (43), but mice in which SCL expression is deleted after HSC specification (44) are able to maintain hematopoiesis, and HSC self-renewal progresses normally.

Similar to Notch signaling, Wnt and Shh are signaling molecules that control many developmental processes and are dysregulated in many human cancers. They have also recently been implicated in the regulation of HSC self-renewal. Human HSCs $\left(\mathrm{CD}^{2} 4^{+} \mathrm{Lin}^{-} \mathrm{CD} 38^{-}\right)$exhibit increased self-renewal in response to Shh signaling in vitro (45). Shh promotes proliferation and retards differentiation of normal cerebellar precursors and other central nervous system (CNS) precursors $(46,47)$, and mutations in the Shh signaling pathway lead to medulloblastoma (48) and basal cell carcinoma (49), suggesting this pathway may promote self-renewal in a variety of normal and cancerous tissues as well. Recent evidence also suggests that Wnt signaling has an important regulatory role in hematopoietic progenitors/stem cells during both fetal and adult development (reviewed in Reference 50). Experiments conducted in both mouse and human progenitors suggested an increase in immature in vitro colony formation in response to conditioned media containing Wnt proteins $(51,52)$. Furthermore, simulating Wnt signaling by overexpression of activated $\beta$-catenin (a downstream mediator of Wnt signaling) in long-term cultures of purified HSCs expands the pool of HSCs as determined by phenotype in vitro and functional transplantation in vivo (53). Moreover, ectopic expression of Axin, an inhibitor that acts by degrading $\beta$-catenin, leads to the inhibition of HSC proliferation and reduced reconstitution in vivo, suggesting that this pathway is also important for maintenance of HSC proliferation and survival in vitro and in vivo. Purified HSCs proliferate in response to soluble Wnt protein in synergy with stem cell factor (SCF) while maintaining the 
REVIEW

Table 1. Summary of Selected Mutant Mice that Exhibit Alterations in HSC Function

\begin{tabular}{|c|c|c|c|c|c|}
\hline Gene & Description & $\begin{array}{l}\text { Type of } \\
\text { Mutant }\end{array}$ & Effects on HSC Function In Vivo & Effects on HSC Function In Vitro & $\begin{array}{c}\text { References } \\
\text { (No.) }\end{array}$ \\
\hline$B m i-1$ & $\begin{array}{l}\text { Polycomb group } \\
\text { transcription factor }\end{array}$ & Knock-out & $\begin{array}{l}\text { Reduced HSC frequency in bone marrow. } \\
\text { Inability to contribute to PB in repopula- } \\
\text { tion assay. } \\
\text { Up-regulation of } p 16^{\text {Ink4a }} \text { and p19Arf. }\end{array}$ & $\begin{array}{l}\text { Reduction in progenitor frequency } \\
\text { by CFC assay. Overexpression } \\
\text { of p16 }{ }^{\text {Ink4a }} \text { decreased HSC } \\
\text { proliferation and overexpression of } \\
\text { p19Arf increased p53-dependent } \\
\text { cell death. }\end{array}$ & $(15,16)$ \\
\hline$p 27$ & $\begin{array}{l}\text { Cyclin-dependent } \\
\text { kinase inhibitor }\end{array}$ & Knock-out & $\begin{array}{l}\text { Committed progenitors but not stem cells } \\
\text { have increased fraction of cells in cycle. } \\
\text { Preferential outgrowth of progenitor and } \\
\text { mature cells during competitive repopula- } \\
\text { tion assay. }\end{array}$ & $\begin{array}{l}\text { Expansion of progenitor popula- } \\
\text { tion indicated by CFC assay. }\end{array}$ & $(27)$ \\
\hline$C B P$ & $\begin{array}{l}\text { Transcriptional } \\
\text { co-activator }\end{array}$ & Knock-out & $\begin{array}{l}\mathrm{CBP}^{+/-} \mathrm{HSC} \text { exhaust prematurely during } \\
\text { serial transplantation. } \\
\text { No PB contribution from } \mathrm{CBP}^{-/-} \text {cells in } \\
\text { blastocyst chimeras. }\end{array}$ & $\begin{array}{l}\text { No defect in hematopoietic differ- } \\
\text { entiation of } \mathrm{CBP}^{-/-} \text {ES cells. }\end{array}$ & $(29)$ \\
\hline $\begin{array}{l}\text { HoxB3/ } \\
\text { B4 }\end{array}$ & $\begin{array}{l}\text { Transcription } \\
\text { factors }\end{array}$ & Knock-out & $\begin{array}{l}\text { Delayed HSC regenerative capacity in } \\
\text { competitive repopulation assay. } \\
\text { Reduced number of cells in cycle after } \\
\text { cytoxan treatment. }\end{array}$ & $\begin{array}{l}\text { Small reduction in proliferative } \\
\text { capacity of HSC containing } \\
\text { fraction. }\end{array}$ & $(21)$ \\
\hline$P b x-1$ & $\begin{array}{l}\text { Transcription } \\
\text { cofactor for Hox } \\
\text { and Meis family } \\
\text { proteins }\end{array}$ & Knock-out & $\begin{array}{l}\text { Reduced ability of FL HSCs to repopulate } \\
\text { peripheral blood in competitive reconsti- } \\
\text { tution assays. }\end{array}$ & $\begin{array}{l}\text { Reduced proliferative ability of } \\
\text { committed progenitors. }\end{array}$ & (7) \\
\hline Sca-1 & $\begin{array}{l}\text { Cell-surface } \\
\text { antigen }\end{array}$ & Knock-out & $\begin{array}{l}\text { Reduced frequency of CFU-S. } \\
\text { Reduced repopulation efficiency in } \\
\text { competitive and serial transplantation } \\
\text { experiments. }\end{array}$ & Reduced numbers of CFU-GEMM. & (31) \\
\hline TERT & $\begin{array}{l}\text { Catalytic compo- } \\
\text { nent of telomerase }\end{array}$ & Knock-out & $\begin{array}{l}\text { Enhanced telomere shortening in HSCs } \\
\text { during serial transplantation. } \\
\text { Deficient HSCs exhaust prematurely after } \\
\text { two rounds of serial transplantation. }\end{array}$ & NA & (34) \\
\hline TERT & $\begin{array}{l}\text { Catalytic compo- } \\
\text { nent of telomerase }\end{array}$ & Transgenic & $\begin{array}{l}\text { No difference in HSC frequency or extent } \\
\text { of serial transplantation. }\end{array}$ & NA & (35) \\
\hline$B C L 2$ & $\begin{array}{l}\text { Inhibitor of cell } \\
\text { death }\end{array}$ & Transgenic & $\begin{array}{l}\text { Higher frequency of LT-HSCs in bone } \\
\text { marrow. } \\
\text { Greater contribution from HSCs to total } \\
\text { blood pool in competitive reconstitution } \\
\text { assays. }\end{array}$ & $\begin{array}{l}\text { Increased plating efficiency and } \\
\text { protection against growth factor- } \\
\text { deprivation apoptosis. }\end{array}$ & $(11)$ \\
\hline
\end{tabular}


phenotypic and functional characteristics of HSCs, suggesting that multiple elements of this pathway can act as stem cell growth factors (54). Interestingly, studies also suggest that certain Wnt family members (specifically Wnt5A) may also have a positive impact on human hematopoietic progenitor and stem cell growth when injected in xenograft models in vivo (55). The studies described above indicate that Wnt signaling is important in the maintenance and self-renewal of hematopoietic stem and progenitor cells. Importantly, besides its role in the hematopoietic system, Wnt signaling also regulates self-renewal and maintenance of stem cells and progenitors in tissues as diverse as the nervous system, the gut, and the human epidermis (reviewed in Reference 50). Since Notch, Shh, and Wnt appear to be strong inducers of self-renewal in multiple contexts, it will be extremely important for future studies to focus on defining their role in HSCs in context of the native microenvironment through the use of transgenic and knock-out mouse models.

\section{PERSPECTIVES}

At a cellular level, a stem cell must survive, proliferate, and remain undifferentiated in order to self-renew successfully. But what does self-renewal mean at a molecular level? The molecular program must include genes that regulate the cell cycle, those that prevent cell death, as well as those that inhibit differentiation. The data discussed in this review point to several elements that appear to control separate components of this self-renewal process, such as survival, proliferation, or quiescence. These genes appear to act in HSCs in much the same manner as they do in other tissues and cells. However, the ability of HSCs to renew long term is unique and a property that is not shared by most other cells. Thus, even if the machinery in stem cells and other somatic cells is the same, it is tempting to speculate that there are master regulators uniquely expressed in stem cells that can coordinate these programs in their entirety to maintain self-renewal ability throughout life. If such master regulators could be identified and harnessed, it would revolutionize our understanding of stem cell biology and our ability to utilize stem cells for therapy.

\section{ACKNOWLEDGMENTS}

We wish to thank Andy Duncan, Jos Domen, and David Scadden for helpful comments and discussions. We apologize to colleagues whose work may not be represented due to space constraints. T.R. is supported by the Cancer Research Institute Investigator Award, Ellison Medical Foundation New Scholar Award, and funds from the National Institutes of Health.

\section{REFERENCES}

1.Till, J. and E. McCulloch. 1961. A direct measurement of the radiation sensitivity of normal mouse bone marrow cells. Radiat. Res. 14:213-222.

2.Spangrude, G.J. and G.R. Johnson. 1990. Resting and activated subsets of mouse multipotent hematopoietic stem cells. Proc. Natl. Acad. Sci. USA 87:7433-7437.

3.Goodell, M.A., K. Brose, G. Paradis, A.S. Conner, and R.C. Mulligan. 1996. Isolation and functional properties of murine hematopoietic stem cells that are replicating in vivo. J. Exp. Med. 183:1797-1806.

4.Visser, J.W.M., J.G.J. Gauman, A.H. Mulder, J.F. Eliason, and A.W. de Leeuw. 1984. Isolation of murine pluripotent hemopoietic stem cells. J. Exp. Med. 59:1576-1590.

5.Osawa, M., K. Hanada, H. Hamada, and H. Nakauchi. 1996. Longterm lymphohematopoietic reconstitution by a single CD34- low/negative hematopoietic stem cell. Science 273:242-245.

6.Adolfsson, J., O.J. Borge, D. Bryder, K. Theilgaard-Monch, I. Astrand-Grundstrom, E. Sitnicka, Y. Sasaki, and S.E. Jacobsen. 2001 Upregulation of Flt3 expression within the bone marrow Lin(-)Sca1(+)ckit(+) stem cell compartment is accompanied by loss of self-renewal capacity. Immunity 15:659-669.

7.Christensen, J.L. and I.L. Weissman. 2001. Flk-2 is a marker in hematopoietic stem cell differentiation: a simple method to isolate long-term stem cells. Proc. Natl. Acad. Sci. USA 98:14541-14546.

8.Spangrude, G.J., S. Heimfeld, and I.L. Weissman. 1988. Purification and characterization of mouse hematopoietic stem cells [published erratum appears in Science 1989 Jun 2;244(4908):1030]. Science 241:58-62.

9.Uchida, N. and I.L. Weissman. 1992. Searching for hematopoietic stem cells: evidence that Thy-1.11o Lin- Sca-1+ cells are the only stem cells in C57BL/Ka-Thy-1.1 bone marrow. J. Exp. Med. 175:175-184.

10.Morrison, S.J. and I.L. Weissman. 1994. The long-term repopulating subset of hematopoietic stem cells is deterministic and isolatable by phenotype. Immunity 1:661-673.

11.Domen, J., S.H. Cheshier, and I.L. Weissman. 2000. The role of apoptosis in the regulation of hematopoietic stem cells: overexpression of Bcl-2 increases both their number and repopulation potential. J. Exp. Med. 191:253-264.

12.Domen, J., K.L. Gandy, and I.L. Weissman. 1998. Systemic overexpression of BCL-2 in the hematopoietic system protects transgenic mice from the consequences of lethal irradiation. Blood 91:2272-2282.

13.Huang, D.C., L.A. O'Reilly, A. Strasser, and S. Cory. 1997. The antiapoptosis function of Bcl-2 can be genetically separated from its inhibitory effect on cell cycle entry. EMBO J. 16:4628-4638.

14.O'Reilly, L.A., D.C. Huang, and A. Strasser. 1996. The cell death inhibitor Bcl-2 and its homologues influence control of cell cycle entry. EMBO J. 15:6979-6990.

15.Park, I.K., D. Qian, M. Kiel, M.W. Becker, M. Pihalja, I.L. Weissman, S.J. Morrison, and M.F. Clarke. 2003. Bmi-1 is required for maintenance of adult self-renewing haematopoietic stem cells. Nature 423:302-305.

16.Lessard, J. and G. Sauvageau. 2003. Bmi-1 determines the proliferative capacity of normal and leukaemic stem cells. Nature 423:255-260.

17.Jacobs, J.J., K. Kieboom, S. Marino, R.A. DePinho, and M. van Lohuizen. 1999. The oncogene and Polycomb-group gene bmi-1 regulates cell proliferation and senescence through the ink4a locus. Nature 397: 164-168.

18.Reya, T., S.J. Morrison, M.F. Clarke, and I.L. Weissman. 2001. Stem cells, cancer, and cancer stem cells. Nature 414:105-111.

19.Molofsky, A.V., R. Pardal, T. Iwashita, I.K. Park, M.F. Clarke, and S.J. Morrison. 2003. Bmi-1 dependence distinguishes neural stem cell self-renewal from progenitor proliferation. Nature 425:962-967.

20.Antonchuk, J., G. Sauvageau, and R.K. Humphries. 2002. HOXB4induced expansion of adult hematopoietic stem cells ex vivo. Cell 109: 39-45.

21.Bjornsson, J.M., N. Larsson, A.C. Brun, M. Magnusson, E. Andersson, P. Lundstrom, J. Larsson, E. Repetowska, et al. 2003. Reduced proliferative capacity of hematopoietic stem cells deficient in Hoxb3 and Hoxb4. Mol. Cell. Biol. 23:3872-3883.

22.Magli, M.C., C. Largman, and H.J. Lawrence. 1997. Effects of HOX homeobox genes in blood cell differentiation. J. Cell Physiol. 173:168177.

22a.DiMartino, J.F., L. Selleri, D. Traver, M.T. Firpo, J. Rhee, R. Warnke, S. O'Gorman, I.L. Weissman, and M.L. Cleary. 2001. The Hox cofactor and proto-oncogene $\mathrm{Pbx} 1$ is required for maintenance of definitive hematopoiesis in the fetal liver. Blood 98:618-626.

23.Yu, B.D., J.L. Hess, S.E. Horning, G.A. Brown, and S.J. Korsmeyer. 1995. Altered Hox expression and segmental identity in Mll-mutant mice. 
Nature 378:505-508.

24.Yagi, H., K. Deguchi, A. Aono, Y. Tani, T. Kishimoto, and T. Komori. 1998. Growth disturbance in fetal liver hematopoiesis of Mll-mutant mice. Blood 92:108-117.

25.Cheshier, S.H., S.J. Morrison, X. Liao, and I.L. Weissman. 1999. In vivo proliferation and cell cycle kinetics of long-term hematopoietic stem cells. Proc. Natl. Acad. Sci. USA 96:3120-3125.

26.Cheng, T., N. Rodrigues, H. Shen, Y. Yang, D. Dombkowski, M. Sykes, and D.T. Scadden. 2000. Hematopoietic stem cell quiescence maintained by $\mathrm{p} 21 \mathrm{cip} 1 /$ waf1. Science 287:1804-1808.

27.Cheng, T., N. Rodrigues, D. Dombkowski, S. Stier, and D.T. Scadden. 2000. Stem cell repopulation efficiency but not pool size is governed by p27(kip1). Nat. Med. 6:1235-1240.

28.Ohta, H., A. Sawada, J.Y. Kim, S. Tokimasa, S. Nishiguchi, R.K. Humphries, J. Hara, and Y. Takihara. 2002. Polycomb group gene rae28 is required for sustaining activity of hematopoietic stem cells. J. Exp. Med. 195:759-770.

29.Rebel, V.I., A.L. Kung, E.A. Tanner, H. Yang, R.T. Bronson, and D.M. Livingston. 2002. Distinct roles for CREB-binding protein and p300 in hematopoietic stem cell self-renewal. Proc. Natl. Acad. Sci. USA 99: 14789-14794

30.Kung, A.L., V.I. Rebel, R.T. Bronson, L.E. Ch'ng, C.A. Sieff, D.M. Livingston, and T.P. Yao. 2000. Gene dose-dependent control of hematopoiesis and hematologic tumor suppression by CBP. Genes Dev. 14: 272-277.

31.Ito, C.Y., C.Y. Li, A. Bernstein, J.E. Dick, and W.L. Stanford. 2003. Hematopoietic stem cell and progenitor defects in Sca-1/Ly-6A-null mice. Blood 101:517-523.

32.Morrison, S.J., K.R. Prowse, P. Ho, and I.L. Weissman. 1996. Telomerase activity in hematopoietic cells is associated with self- renewal potential. Immunity 5:207-216.

33.Allsopp, R.C., S. Cheshier, and I.L. Weissman. 2001. Telomere shortening accompanies increased cell cycle activity during serial transplantation of hematopoietic stem cells. J. Exp. Med. 193:917-924.

34.Allsopp, R.C., G.B. Morin, R. DePinho, C.B. Harley, and I.L. Weissman. 2003. Telomerase is required to slow telomere shortening and extend replicative lifespan of HSCs during serial transplantation. Blood 102:517-520.

35.Allsopp, R.C., G.B. Morin, J.W. Horner, R. DePinho, C.B. Harley, and I.L. Weissman. 2003. Effect of TERT over-expression on the longterm transplantation capacity of hematopoietic stem cells. Nat. Med. 9: 369-371.

36.Varnum-Finney, B., L. Xu, C. Brashem-Stein, C. Nourigat, D. Flowers, S. Bakkour, W.S. Pear, and I.D. Bernstein. 2000. Pluripotent, cytokine-dependent, hematopoietic stem cells are immortalized by constitutive Notch1 signaling. Nat. Med. 6:1278-1281.

37.Stier, S., T. Cheng, D. Dombkowski, N. Carlesso, and D.T. Scadden. 2002. Notch1 activation increases hematopoietic stem cell self-renewal in vivo and favors lymphoid over myeloid lineage outcome. Blood 99: 2369-2378.

38.Karanu, F.N., B. Murdoch, L. Gallacher, D.M. Wu, M. Koremoto, S. Sakano, and M. Bhatia. 2000. The notch ligand jagged-1 represents a novel growth factor of human hematopoietic stem cells. J. Exp. Med. 192: 1365-1372.

39.Artavanis-Tsakonas, S., K. Matsuno, and M.E. Fortini. 1995. Notch Signaling. Science 268:225-232.

40.Kumano, K., S. Chiba, A. Kunisato, M. Sata, T. Saito, E. NakagamiYamaguchi, T. Yamaguchi, S. Masuda, et al. 2003. Notch1 but not Notch2 is essential for generating hematopoietic stem cells from endothelial cells. Immunity 18:699-711.

41.Radtke, F., A. Wilson, G. Stark, M. Bauer, J. van Meerwijk, H.R. MacDonald, and M. Aguet. 1999. Deficient T cell fate specification in mice with an induced inactivation of Notch1. Immunity 10:547-558.

42.Calvi, L.M., G.B. Adams, K.W. Weibrecht, J.M. Weber, D.P. Olson, M.C. Knight, R.P. Martin, E. Schipani, et al. 2003. Osteoblastic cells regulate the haematopoietic stem cell niche. Nature 425:841-846.

43.Porcher, C., W. Swat, K. Rockwell, Y. Fujiwara, F.W. Alt, and S.H. Orkin. 1996. The T cell leukemia oncoprotein SCL/tal-1 is essential for development of all hematopoietic lineages. Cell 86:47-57.

44.Mikkola, H.K., J. Klintman, H. Yang, H. Hock, T.M. Schlaeger, Y. Fujiwara, and S.H. Orkin. 2003. Haematopoietic stem cells retain longterm repopulating activity and multipotency in the absence of stem-cell leukaemia SCL/tal-1 gene. Nature 421:547-551.

45.Bhardwaj, G., B. Murdoch, D. Wu, D.P. Baker, K.P. Williams, K. Chadwick, L.E. Ling, F.N. Karanu, and M. Bhatia. 2001. Sonic hedgehog induces the proliferation of primitive human hematopoietic cells via BMP regulation. Nat. Immunol. 2:172-180.

46.Rowitch, D.H., S.-Jacques B., S.M. Lee, J.D. Flax, E.Y. Snyder, and A.P. McMahon. 1999. Sonic hedgehog regulates proliferation and inhibits differentiation of CNS precursor cells. J. Neurosci. 19:8954-8965.

47.Wechsler-Reya, R.J. and M.P. Scott. 1999. Control of neuronal precursor proliferation in the cerebellum by Sonic Hedgehog. Neuron 22: 103-114.

48.Wechsler-Reya, R. and M.P. Scott. 2001. The developmental biology of brain tumors. Annu. Rev. Neurosci. 24:385-428.

49.Gailani, M.R. and A.E. Bale. 1999. Acquired and inherited basal cell carcinomas and the patched gene. Adv. Dermatol. 14:261-283.

50.Reya, T. 2003. Regulation of hematopoietic stem cell self-renewal. Recent Prog. Horm. Res. 58:283-295.

51.Austin, T.W., G.P. Solar, F.C. Ziegler, L. Liem, and W. Matthews. 1997. A role for the Wnt gene family in hematopoiesis: expansion of multilineage progenitor cells. Blood 89:3624-3635.

52.Van Den Berg, D.J., A.K. Sharma, E. Bruno, and R. Hoffman. 1998 Role of members of the Wnt gene family in human hematopoiesis. Blood 92:3189-3202.

53.Reya, T., A.W. Duncan, L. Ailles, J. Domen, D.C. Scherer, K. Willert, L. Hintz, R. Nusse, and I.L. Weissman. 2003. A role for Wnt signalling in self-renewal of haematopoietic stem cells. Nature 423:409-414.

54.Willert, K., J.D. Brown, E. Danenberg, A.W. Duncan, I.L. Weissman, T. Reya, J.R. Yates III, and R. Nusse. 2003. Wnt proteins are lipid-modified and can act as stem cell growth factors. Nature 423:448-452.

55.Murdoch, B., K. Chadwick, M. Martin, F. Shojaei, K.V. Shah, L. Gallacher, R.T. Moon, and M. Bhatia. 2003. Wnt-5A augments repopulating capacity and primitive hematopoietic development of human blood stem cells in vivo. Proc. Natl. Acad. Sci. USA 100:3422-3427.

\section{Address correspondence to:}

Tannishtha Reya

C333 LSRC

Department of Pharmacology and Cancer Biology

Duke University Medical Center

Durham, NC 27710, USA

e-mail:t.reya@duke.edu 